\title{
A Study on Significance of Backwater Tourism and Safe Houseboat Operation in Kerala
}

\author{
Jiju Jose $^{1} \&$ P. S. Aithal ${ }^{2}$ \\ ${ }^{1}$ Research Scholar, College of Management and Commerce, Srinivas University, Mangalore, India \\ E-mail: jijutourism@gmail.com \\ ${ }^{2}$ Professor, College of Management \& Commerce, Srinivas University, Mangalore, India \\ E-mail: psaithal@gmail.com
}

Area/Section: Business Management.

Type of the Paper: Review based Analysis.

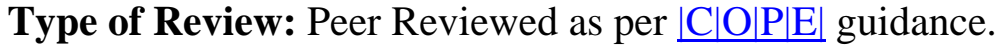

Indexed in: OpenAIRE.

DOI: http://doi.org/10.5281/zenodo.4007485.

Google Scholar Citation:IJMTS.

\section{How to Cite this Paper:}

Jose, Jiju,\& Aithal, P. S. (2020). A Study on Significance of Backwater Tourism and Safe Houseboat Operation in Kerala. International Journal of Management, Technology, and Social Sciences (IJMTS), 5(2), 133-140. DOI: http://doi.org/10.5281/zenodo.4007485.

International Journal of Management, Technology, and Social Sciences (IJMTS)

A Refereed International Journal of Srinivas University, India.

(C) With Authors.

\section{(c) (7) (5)}

This work is licensed under a Creative Commons Attribution-Non-Commercial 4.0 International License subject to proper citation to the publication source of the work.

Disclaimer: The scholarly papers as reviewed and published by the Srinivas Publications (S.P.), India are the views and opinions of their respective authors and are not the views or opinions of the SP. The SP disclaims of any harm or loss caused due to the published content to any party. 


\title{
A Study on Significance of Backwater Tourism and Safe Houseboat Operation in Kerala
}

\author{
Jiju Jose ${ }^{1} \&$ P. S. Aithal ${ }^{2}$ \\ ${ }^{1}$ Research Scholar, College of Management and Commerce, Srinivas University, Mangalore, India \\ E-mail: jijutourism@gmail.com \\ ${ }^{2}$ Professor, College of Management \& Commerce, Srinivas University, Mangalore, India \\ E-mail: psaithal@gmail.com
}

\begin{abstract}
The Backwaters of Kerala are historically important. The backwaters and interconnecting navigable canals have made a number of rural tourism destinations with matchless beauty.These backwater systems were once Kerala's own trade highways. The major component of backwater tourism is houseboat cruising.The State has sensed the potential of backwater tourism in nowadays.Mass tourism movement in this sector caused for the multidimensional impacts on the economic,socio-cultural and bio-physical environment.Being an Eco-tourism product, backwater tourism needs sustainable and responsible tourism practice. Considering the need for the sustenance of the houseboat operation as a unique tourismproduct,it is mandatory to ensure the quality of facilities and services. In this paper, the researcher is trying to focus on the importance of backwater tourismin Kerala. Also giving special attention to identify various aspects of safe houseboat operations and the issues related. The major issues related to houseboat operation are lack of infrastructure,issues of licensing,issues of safety, environmental issues, and lack of quality services.In this study, the researcher is highlighting the need for the sustenance of the house boating by giving effective recommendations to reduce the negative aspects.
\end{abstract}

Keywords:Back water tourism, House boat operations and unique tourism product.

\section{INTRODUCTION :}

Backwaters of Kerala are a major tourist attraction and it may be considered as one of the unique tourism products of the state [1]. Compared to other states of India Kerala's tourism potential is very high. The Kerala state may be the tourism trendsetter in the nation [2]. The State has so many attributes such as highest literacy, life expectancy and lowest maternal and child mortality rates. The state's most attractive sectors are its wonderful climate, backwaters, local cuisine, culture, arts and crafts, historic monuments, religious rituals and traditional accommodation facility [3]. Kerala's vast coastlines made so many panoramic beaches. Year old Ayurveda treatment facilities, festivals, heritage sites are another major wonder of Kerala.Kerala's backwaters and interconnecting navigable canals have made a number of rural tourism destinations with fragile ecosystem teaming with aquatic biodiversity.

Kerala backwaters are the part of wetland system [4]. These backwater systems were once Kerala's own trade highways. The backwaters of Kerala are historically important. Its matchless beauty and outstanding experiences are plenty. The major component of back-water tourism is the houseboat cruising. It attracts a large number of international and domestic tourists. The "Venice of east" Alappuzha has become the hub of back water-based tourism activities. At present more than 2000 houseboats are operating in Vembanadu Lake. Now a day the local community nearby area of backwaters is strongly dependenton tourism activities for their livelihood. One or two members from each family are presently engaged in tourism activities as houseboat crews or other employment related to houseboat operation.This shift of employment from the agriculture sector to the tourism sector highly influenced the local community's perception of the traditional agricultural activities [5]. Because of Tourism development in the backwater area, happened the 
multidimensional impact on the region.

The uncontrolled growth of the number of houseboat operations and other tourism activities adversely affected the environmental systems, the livelihood of the area, etc. Here in this study focuses on the significances of backwater tourism specially refers to safe houseboat operations.

\section{RELATED WORK :}

There have been very few studies and literature available in the area of Kerala backwater tourism and houseboat operations. Many of them are based on different aspects. By analyzing the literature and studies of various impacts of backwater tourism, the commonality observed is that backwater tourism can make socio, economic, cultural, and environmental effects on the host community. It can change traditional lifestyles, value concepts, community structures and relationships. Backwater tourism is caused for regional development through local employment generation and foreign exchange generation. Even though it has negative socio-environmental impacts. It also caused negative impacts on bio-physical environments such as soil, air, water pollution, and ecosystem degradation. Changes of local traditional culture, increases in crimes are the best example of negative socio-cultural environmental impacts caused by backwater tourism development. Sri Joseph Chandy and Raghunathan Rajesh in their article "Impact of backwater tourism in Kerala” reviewed conceptually and theoretically the interrelation between impacts of backwater tourism towards environmental attributes of the lake [6]. According to them the mass tourism movement in the backwater region made adverse impacts on the environment. Backwater tourism activities such as boating, snorkeling, diving and fishing, and improper and irresponsible behavior of tourists caused detrimental effects on the environmental attributes.In a paper presented in the national conference and tourism in India organized by IIM Calicut and IIM Lucknow held on $15^{\text {th }}$ May 2008 by Sri Zechariah, Siby, James Manalel, Jose M C and Afsal Salam pointed out the vital role of houseboats (kettuvallam) in the back-water tourism. According to them, houseboats are an integral part of the backwater tourism [24]. In an article, History of reclaimed Kayals in Kuttanadu wetland and associated social divide in Alappuzha district Kerala, by SarathChandran et al observes that the level of Kayal reclamation in backwater tourism regions [7].Babu Paul, D. in his article a' perspective paper on tourism development in Kerala' points out that backwater tourism is an eco-tourism product and its positive impact on the total tourism development is plenty [8]. RymalaMattan studies in the article Houseboats in Kerala - constructional issues and environmental issues[9], threw light on the current issues facing the houseboat operations in Kerala.

\section{OBJECTIVES :}

The present study tries to highlight the significance of Kerala backwater tourism and the importance of safe houseboat operation as a prime tourism product.In this study, the researcher is trying to identify the major issues facing the houseboat operations. Also, recommend effective solutions for safe and secured houseboat operations.

\section{METHODOLOGY :}

In this study, the researcher is adopting a historical descriptive, analytical and socio-economic approach method. Apart from literature, information has been collected through personal interactions with the officials of central and state tourism departments, port department, irrigation department, local community members and stakeholders of the industry.

\section{IMPORTANCE OF BACKWATERS IN KERALA TOURISM :}

Kerala has sensed the potential of backwater tourism now a day. The expansive body of brackish waters is commonly called as backwaters [10]. The total of Kerala backwaters area is over 2,00,000 hectares. Kerala backwaters are the part of Ramsar wetland system [11]. The backwaters include lagoons, estuaries and river deltas, and interconnected canals. The backwaters of Kerala providing excellent water transportations in the coastal plains. The most common tourism relating activities are houseboat cruising, Ayurveda rejuvenation centres at the banks of backwaters, water sports facilities and community based responsible tourism 
activities. Kerala backwaters have a unique ecosystem [12]. Kerala backwaters are spread over Alappuzha, Kottayam, Kollam, Kozhikode, Kasargod and Ernakulum districts.The national waterway from Kollam to Kottappuram covers a distance of 205 kms. It facilitating both cargo movement and backwater tourism.

As a major product, the backwaters are playing a vital role in the total tourism sector of Kerala. Backwaters contribute a wide range of socio-economic environmental and biological impacts. It also provides a safe and ideal means of transportation for goods and people. The major economic activities in the backwaters include tourism, agriculture, fisheries, lime shell mining, etc. The Kerala backwater system, directly and indirectly, supports a large number of people providing goods and services. The importance of backwater tourism in Kerala has been the topic of much research report. Under the 'Final Report on 20 Year Perspective Plan for the development of sustainable tourism for the State of Kerala'for Ministry of Tourism and Culture, Government of India prepared by Tata Economic Consultancy Services, backwaters of Kerala occupy the third position next to heritage and beaches among foreign tourists and second position next to heritage among domestic tourists (table 1).

Table 1:Plan for development of tourism for Kerala [11]

\begin{tabular}{|c|c|c|}
\hline Tourism product category & Domestic tourists - \% & Foreign tourists - \% \\
\hline Heritage, culture and religion & 65 & 40 \\
\hline Backwaters & 15 & 20 \\
\hline Beaches & 8 & 25 \\
\hline Hills and Hill stations & 7 & 5 \\
\hline Forest and Wildlife & 5 & 10 \\
\hline
\end{tabular}

'Final Report on 20 Year Perspective Plan for development of tourism for Kerala' - TECS

In the study Kerala's approach to tourism development by CRISIL,points out that the backwaters of Kerala average a high mean score among the features of Kerala. Backwaters rank next to natural beauty and safety among the features.

Table 2:Kerala tourism development opportunities as per CRISIL [11]

\begin{tabular}{|c|c|c|c|}
\hline Features of Kerala & Total mean score & $\begin{array}{c}\text { Domestic tourists - } \\
\text { mean score }\end{array}$ & $\begin{array}{c}\text { Foreign tourists - mean } \\
\text { score }\end{array}$ \\
\hline Natural beauty & 4.51 & 4.57 & 4.47 \\
\hline Beaches & 3.74 & 3.85 & 3.66 \\
\hline Backwaters & 4.34 & 4.32 & 4.35 \\
\hline Tea gardens & 4.03 & 4.28 & 3.80 \\
\hline Islands & 3.78 & 3.97 & 3.62 \\
\hline Culture and Heritage & 4.26 & 4.15 & 3.34 \\
\hline Palaces and Churches & 3.82 & 3.86 & 4.21 \\
\hline Cuisine & 4.04 & 3.82 & 3.89 \\
\hline Ayurveda & 3.99 & 4.11 & 3.82 \\
\hline Wildlife and Birdlife & 3.84 & 3.86 & 3.88 \\
\hline Climate & 4.03 & 4.22 & 4.36 \\
\hline Safety & 4.41 & 4.47 & 4.06 \\
\hline Hotels & 4.17 & 4.30 & 4.25 \\
\hline Connectivity & 4.30 & 4.37 & 4.22 \\
\hline Economical & 4.25 & 4.29 & 4.39 \\
\hline Others & 4.31 & 4.20 & \\
\hline
\end{tabular}

‘Kerala’s approach to Tourism Development - A case study’ - CRISIL

\section{IMPACTS OF BACKWATER TOURISM :}

Mass tourism movement inthe backwater region rises multi-dimensional impacts - economic, socio-cultural and bio-physicalenvironment. The houseboat operation is the prime component of backwater tourism. 
Hotels, homestays, resorts are another integral part of backwater tourism. Responsible tourism activities such as toddy tapping, fishing by Cheenavala, country boats rally, various craftwork are the major opportunities of backwater tourism.Backwater tourism activities generate skilled and unskilled employment opportunities, foreign exchange and local trading. Another important thing to consider is the shift in employment. One or two members of each family presently engaged in tourism activities as houseboat operators, hospitality service providers and shop makers.

The change in the employment sector from agriculture to the tourism sector is caused for attitude change to the traditional agriculture occupation. The employment shift also seriously affected the agriculture production of the region. The uncontrolled and irresponsible practice of tourism is caused for the imbalance of the wetland system, thus the total environmental system of lakes. Tourism development in the backwater region affected socio-cultural changes of the host community. Interaction of the host community with the guest community has changed the perception towards the lifestyle. Preservation of local culture, religious rituals and ceremonies and local crafts, etc are the result of backwater tourism developments.Mass tourism movements in backwater regions made negative impacts on the bio-physical environment such as soil, water, air pollution and ecosystem degradation. The major water-based activities boating snorkeling diving and fishing caused for the environmental imbalance.

\section{HOUSEBOAT OPERATION :}

Houseboat cruising is the major component of backwater tourism. The old country boats or rice boats are converted as houseboats. The houseboat operation started from two decades back with 20 boats. The number of houseboats increased multifold in recent years because of high demand by the tourist. Many of the houseboats are moving palaces with moderate facilities [13]. The houseboats are attracting both national and international tourists. After the development of backwater tourism, local traditional agriculture has shifted to tourism activities. They became houseboat operators and crews.

\section{ISSUES OF HOUSEBOATING :}

The major issues related to houseboat operation are the lack of infrastructure, lack of proper licensing, lack of security, environment issues and absence of quality service. The majority of houseboats are operating in the Vembanadu backwater. The facilities provided are limited. Overcrowding caused for frequent accidents. Both tourists and boat operators are facing inconveniences. In the night, houseboats are parking in rural areas. These places are remote without any facilities like electricity, telecommunication, fuel stations, etc. At present $50 \%$ of the vessels are playing without proper licenses. The entire responsibility of issuing a license to houseboat is vested in the port department but Kerala inland vessel rules are much insufficient for issuing a license to the houseboats. There were many clauses which were impractical for the houseboats. The majority of the houseboats are playing without prescribed standards and cannot be considered as safe for operations. Apart from the license, there are no other means to know the existence of a houseboat. The state Tourism Department doesn't have any power to regulate the houseboat industry. The tourism department is only giving a classification certificate based on facilities. The primary document which is needed for giving the classification certificate is a valid license. Only a few houseboats have a valid license as per the present rules. So, there are practically no classified houseboats plying in the backwaters [14]. This is seriously affecting the image of Kerala tourism and the promotion of this unique tourism product.

At present, the houseboat doesn't have common stations or jetties. They are now parked and operated from any point in the backwaters as desired by the operator without any control. There is not any system to follow the houseboats. There is no system to know the passengers or crews. The major issues related to safety and securities are lack of regulation of houseboat operation, lack of data of the passengers and crews, lack of manpower and equipment patrolling and rescue operations, an inadequate system to locate and identify a particular houseboat, lack of clarity of the duties and responsibilities of each crew.

Another important issue related to the houseboat operation is an environmental issue. Discharge of solid and liquid waste including sewage from houseboats directly to the backwater or to the shore is a serious issue. According to the Port Department, for issuing licenses to the houseboats, it is mandatory to have 
onboard scientific sewage treatment facilities. The major environmental issues identified are lack of sufficient STP (Sewage Treatment Plant), lack of facilities for the collection, and scientific management of solid waste. Houseboat crews are discharging solid and liquid waste directly to the backwater.

Lack of quality service is another major issue related to houseboat operation. Houseboats should maintain the minimum quality standards met to attract quality tourists [15-23]. At present, the parameters for the licensing are the size of the board, stability, manpower, safety, pollution, etc. There is no consideration of the requirement related to hospitality and tourism like the size of rooms, size of the toilet, quality of linen, furniture and décor, quality of food, service, communication skill of the crew and eco-friendliness, etc. Now as per the facilities, licensed houseboats are classified as gold, silver. Eco-friendly houseboats are given Green Palm certificates.

\section{FINDINGS :}

\subsection{Prospects}

Houseboat operations are an integral part of the Kerala backwater tourism industry. A good number of the members of the local community in the region of backwaters depend on houseboat cruising for their livelihood. Houseboat operation is an amalgamation of different services such as food preparation, service, art and craft show, hospitality, etc. It, directly and indirectly, provides a lot of employment opportunities. Local art forms are performing in houseboats as per the requirements of the tourist. Thus, the traditional art forms are preserving as their original forms. Another positive result of the houseboat operation is the uplift of the living standard of the local community. Kerala people are more aware of the environmental standard. So, they are trying to protect their environment without much pollution.

\subsection{ISSUES}

\section{a. Infrastructure}

Lack of infrastructures such as houseboat terminals and check-in checkout points.

Lack of planned night halt centres with basic and safety facilities.

Lack of quality jetties along with the cruise roots.

\section{b. Licensing}

Qualification prescribes by the KIV rule is impractical. Houseboat operation is a traditional industry, so experience needs to be counted. The existing crews shall be accommodated by giving additional skill training. The tourism department of the state should be involved in the licensing and classification criteria.

\section{c. Safe and security operations}

Lack of regulation of houseboat operation with a specific check-in check-out points and night halt points. Lack of data of the passengers and crews onboard, lack of manpower and equipment for patrolling and rescue operations, lack of clarity on the responsibility of each crew member on the safety and security aspects.

\section{d. Environmental issues}

Lack of sufficient STPs onshore to discharge the sewage debris from the houseboat. Lack of facilities for the collection and management of solid wastes generated by the houseboats. The deliberate act of the houseboat crews to discharge solid and liquid waste directly to the backwater. Lack of monitoring mechanism to ensure that the boats don't discharge wastes into the water. Lack of world-class servicerelated tourism and hospitality.

\section{SUGGESTIONS :}

The following suggestions are made based on observation and analysis of reviews in backwater tourism and safe houseboat operation in Kerala :

(1) Establish sufficient boat terminals and jetties with basic and safety infrastructure.

(2) Develop night halt centres and renovate unsafe public jetties along with the cruise roots with support from the water transport department.

(3) Do the annual safety audit of all jetties and night halt centres. 
(4) To implement proper licensing and classification systems, the Tourism Department should play a vital role to the licensing procedures.

(5) To do the safety auditing of house boats and publish the list ofsafety certified boats.

(6) To identify the safe routes for cruising, regulate the houseboat traffic.

(7) Each houseboat shall have a passenger register.

(8) A proper system should be introduced to track the houseboat and to conduct periodical training programmes.

(9) Auditing of the existing onboard sewage treatment system to implement sewage treatment plants in houseboat terminals. To introduce a regular system of collection of solid waste from the houseboats by sewage transporting vessels. Regular collection and disposal of solid wastes from the houseboat routes in the lake.

(10) To give special incentives to the houseboat operators for the introduction of environment friendly practices.

(11) To restrict the number of houseboats based on the carrying capacity of the backwater with respect to environmental and infrastructural aspects.

(12) To formulate legislation to make the approval of houseboat by Department of Tourism mandatory.

(13) To introduce code of conduct for the crew as wellas the passengers.

\section{CONCLUSION :}

The potential ofKerala backwater tourism industry is very high. Being an Eco tourism product, backwater tourism needs sustainable and responsible tourism practice. The houseboat cruising is the pioneer activity of backwater tourism. Its demand is very high. Considering the need for sustenance of this unique tourism product, it is mandatory to ensure the quality of facilities and services provided in the house boats including code of conduct of the green tourism practice.

\section{REFRENCES:}

[1] Vijayakumar, A.(1998). New Strategy for Indian Tourist Industry. Southern Economist, 37(10), 1-24.

[2] Kerala Tourism Statistics, 2018 Dept. Tourism Govt. of Kerala. https://www.keralatourism.org/tourismstatistics/tourist statistics 2018 book20191211065455.pdf

Retrieved on 10/04/2020.

[3] Netto, N. (2004). Tourism development in Kerala. Kerala's economic development: Performance and problems in the post-liberalization period, 269-292.

[4] State of the Environmental Report Govt. of Kerala 2007, Volume 1.http://www.kerenvis.nic.in/PublicationDetails.aspx?SubLinkId=140\&LinkId=810\&Year=2011.

Retrieved on 10/04/2020.

[5] MurugadasR, \&Badaruddin Mohamed (2014). Impacts of Tourism on Environmental Attributes, Environmental literacy and Willingness to pay, a conceptual and theoretical Review.Procedia Social and Behavior Sciences,144(1), 378-391.

[6] Joseph Chandy and Reghunathan Rajesh (2017). Impacts of Backwater Tourism in Kerala.International Journal of Advanced Engineering and Research Development,4(7), 227-232.

[7] Sarathchandran and Subrata Pukayastha(2019). History of Reclaimed Kayals in Kuttanadu Wetland and Associated social divide in Alappuzha district, Kerala. Transactions, 41(1), 69-80.

[8] Babu Paul D. (1991). A perspective Paper on Tourism Development in Kerala. Dept. of Tourism, Govt. of Kerala, Thiruvananthapuram. 26-27.

[9] Mathen, R. (2012). Houseboats in Kerala-Constructional Features and Environmental Issues. IOSR Journal of Environmental Science, Toxicology and Food Technology, (IOSR-JESTFT), 1(6), 31-43. 
[10] Yesodharan, E. P. (2007). State of the Environment Report of Kerala 2007. Land Environment, Wetlands of Kerala and Environmental Health,4, 1-23.

[11] Jacob, R., Kuruvilla, A., Mahadevan, P., \& Kuruvilla, A. (2011). Product Attractiveness of Kerala of Kerala Houseboats in Promoting Tourism - A Performance Analysis. The International Sounds and Tastes of Tourism Education. In F. Hummel (Ed.), Proceedings of the 2011 Annual International Society of Travel and Tourism Educators (ISTTE) Conference, October 20-22, 2011 in Miami, USA (Vol. 23, pp 63-76). St. Clair Shores, MI: International Society of Travel and Tourism Educators. https://www.istte.org/uploads/4/2/2/1/42218183/proceedings2011.pdf\#page=63

[12] Dileep M.R. Introduction to Tourism Concepts and Impacts, KITTS, Kerala Institute of Tourism and Travel Studies. https://academicimpact.un.org/content/kerala-institute-tourism-and-travel-studies-kitts.

[13] Emilda K. Joseph (2016). Environmental Sustainability and Tourism Activities in backwaters of Kerala. International Journal of Tourism \& Hospitality Reviews, 3(2), 69-74, DOI: 10.18510/ijthr.2016.322.

[14] Report of the Committee on Safety of Houseboats Kerala Tourism Department April 2013.

[15] Kokkranikal, J., \& Morrison, A. (2002). Entrepreneurship and sustainable tourism: The houseboats of Kerala. Tourism and Hospitality Research, 4(1), 7-20.

[16] John, S. (2018). Ecological Tourism Pointers: Analysis on Concepts, Frameworks, and Applications on the Vembanad Lake of Kerala, India. Evolving Paradigms in Tourism and Hospitality in Developing Countries, Ch-8, 161-175.

[17] Joseph, S. C., Chacko, R. V., Joseph, A., Jayan, P. P., \& Raghavan, D. P. (2019, December). LVDC Architecture for Energy Efficient House Boat Hotel Load System. In 2019 National Power Electronics Conference (NPEC) (pp. 1-5). IEEE.

[18] Ajlif, A. M., Joseph, S. C., Jayan, P. P., Raghavan, D. P., Joseph, A., \& Chacko, R. V. (2020, January). Energy Efficient LVDC Architecture for House Boat Hotel Load System. In 2020 IEEE International Conference on Power Electronics, Smart Grid and Renewable Energy (PESGRE2020) (pp. 15). IEEE.

[19] Kumara, H. S. (2019). Integrating Plan for Backwaters Transportation with Tourism Development: A Case Study of Kochi City Region. International Journal of Urban Management and Energy Sustainability, 2(1), 1-8.

[20] Mathew, P., \& Kumar, R. (2014). Responsible Tourism -A Grass Root Level Empowerment Mechanism : Case Study From Kerala. Innovative Issues and Approaches in Social Sciences, 7(1), 53-73.

[21] Joseph, L. C., \&Vasanthi, S. (2017). A study on motivating factors of the tourists about the house boats services in Kumarakom, Aleppey District. International Journal of Advanced Research in Management and Social Sciences, 6(4), 127-150.

[22] Mathen, D. (2012). Houseboats in Kerala - Constructional Features and Environmental Issues. IOSR Journal of Environmental Science, Toxicology and Food Technology, 1(6), 31-43. http://dx.doi.org/10.9790/2402-0163143.

[23] Zacharias, Siby, James Manalel, Jose, M.C., and Afsal Salam (2008). Backwater Tourism in KeralaChallenges and Opportunities. https://www.researchgate.net/publication/306379990_BACK_ WATER _TOURISM_IN_KERALA_CHALLENGES_AND_OPPORTUNITIES. 